Citation: Kirpik, G., The Concept Of Employee's Happiness In Human Resources Management:
A Systematic Literature Review, BMIJ, (2020), 8(3): 2750-2775, doi: http://dx.doi.org/10.15295/bmij.v8i3.1517

\title{
THE CONCEPT OF EMPLOYEE'S HAPPINESS IN HUMAN RESOURCES MANAGEMENT: A SYSTEMATIC LITERATURE REVIEW
}

Gülşen KIRPIK 1

\section{ABSTRACT \\ Keywords: \\ Employee Happiness, \\ Human Resources, \\ Organizational Concepts \\ JEL Codes:}

M10,

M12,

M19

\author{
Received Date (Başvuru Tarihi): \\ $26 / 05 / 2020$ \\ Accepted Date (Kabul Tarihi): \\ $18 / 08 / 2020$ \\ Published Date (Yayın Tarihi): \\ $25 / 09 / 2020$
}

This study was carried out to reveal the importance of employee happiness in terms of Human Resources Management (HRM), to identify organizational concepts and job attitudes related to employee happiness, to accelerate studies on this issue, to guide future researchers and other interested people and to be useful in the literature. In this context, 48 articles published between 1995 and 2020 in the journal "Human Resource Management Review", which was scanned in the Science Citation Index (SCI), were examined through systematic literature review. In the light of the obtained findings, it has been observed that the concept of employee happiness is significantly related to the job attitude, the meaning of the job, the pleasure of work, entertainment at work, safe relationships, perceived justice, attachment styles, emotional loyalty, employee moods, employee cynicism, employee status, employee social skills, employee voice, employee loyalty, employee well-being, work experience, work stress, social relationships, health emotion, passion, high performance and loving job, ethical organizational culture, promotion-oriented self-control system, HR practices according to Miller's "Utilitarian Theory", Pro-Social Rule Breaking (PSRB) and Sustainable HRM strategies. Also, in the conclusion part of the study, suggestions developed for organizational concepts determined to be related to employee happiness in the literature are included.

\footnotetext{
${ }^{1}$ Assist. Prof. Dr., Adıyaman University Faculty of Pharmacy, Department of Pharmacy Management, gkirpik@adiyaman.edu.tr https://orcid.org/0000-0003-4785-9624
} 


\section{İNSAN KAYNAKLARI YÖNETIMIINDE ÇALIŞAN MUTLULUĞU KAVRAMI: SISTEMATIK BİR LITERATÜR TARAMASI}

$\ddot{O Z Z}$

\author{
Anahtar Kelimeler: \\ Çalı̧̧an Mutluluğu, \\ İnsan Kaynakları, \\ Örgütsel Kavramlar
}

JEL Kodlar:

M10,

M12,

M19
Bu çalışma, İnsan Kaynakları Yönetimi (İKY) açısından çalışan mutluluğunun öneminin ortaya konmasl, çalı̧̧an mutluluğu ile ilişkili örgütsel kavramlarm ve iş tutumlarınn belirlenmesi, bu konuya yönelik çalışmalara ivme kazandırlması, gelecekteki araştırmacılara ve diğer ilgililere yol gösterilmesi ve literatürdeki bilgi birikimine faydal olunması amacıyla yapılmıştır. Bu bağlamda Science Citation Index (SCI) veri tabanında taranan "Human Resource Management Review" dergisinde 1995-2020 yillarn arasinda yayınlanan 48 makale sistematik literatür taramasıyla incelenmiştir. Elde edilen bulgular ışı̆̆ında, çalışan mutluluğu kavramının; iş tutumu, işin anlamı, iş keyfi, iş yerinde eğlence, güvenli ilişkiler, algılanan adalet, bağlanma stilleri, duygusal bağlılık, çalışanın ruh halleri, çalışan sinizmi, çalışan statüsü, çalı̧̧anin sosyal becerisi, çalışan sesi, çalışan sadakati çalışan refah, iş deneyimi, iş stresi, sosyal ilişkiler, să̆lik duygu, tutku, yüksek performans ve işini sevme, etik örgüt kültürü, promosyon odakl özdenetim sistemi, Miller' in "Faydacı Teorisi"ne göre İK uygulamalar, Pro-sosyal kural çiğneme (Pro-social Rule BreakingPSRB) ve Sürdürülebilir IKKY stratejileri ile önemli derecede ilişkili olduğu gözlenmiştir. Ayrıca, çalı̧̧manın sonuç bölümünde, literatürde çalı̧̧an mutluluğu ile ilişkili olduğu belirlenen örgütsel kavramlara yönelik geliştirilen önerilere de yer verilmiştir. 


\section{INTRODUCTION}

The concept of happiness has been generally associated with positive psychology in the literature (Joo \& Lee, 2017; Dries, 2013; Carr, 2011; Bouskila-Yam and Kluger, 2011; Judge \& Kammeyer-Mueller, 2011; Fisher, 2010; Wright, 2005; Ryan and Deci, 2001). Therefore, although the concept of happiness is more common in psychology journals, it has become a prevalent and current issue of organizational behaviour, especially in recent years, by being included in the concept of "happiness at work" (Keser, 2018; Wesarat et al., 2015; Singh \& Aggarwal, 2018; Hoise, Willemyns \& Sevastos, 2012; Fisher 2010; Carr, 2010; Scott, 2008).

Employee happiness, which has become the most variable and most crucial resource in today's competitive environment, is essential in the success of organizations because the positive results (intrinsic motivation, job performance, success, continuity, commitment, identification, etc.) provided by the happyproductive employee can only be achieved with employees who are satisfied with work and workplace.

The most striking study, titled "Happiness at Work" (Fisher, 2010), published in the journal "International Journal of Management Reviews" regarding the organizational behaviour studies, was conducted in the form of a literature review. Another article similar to this study, which is an empirical study, examining the effect of perceived organizational support and psychological capital on happiness (Joo and Lee, 2017), was published in the journal "Evidence-based HRM". Besides, the study published in the journal "Asia Pacific Journal of Human Resources" examining the moderators between career success and happiness (Pan and Zhou, 2013) and the effect of managers on the contextual and task performance of the happy-productive worker thesis (Hoise, Willemyns and Sevastos, 2012) studies have been reached. On the other hand, it is another study that supports the literature in the study examining the relationship between happiness and productivity (Oswald, Proto and Sgroi, 2015) published in the journal "Journal of Labor Economics".

It has been stated by Indigo magazine (URL-1) that despite the improvements made in the physical conditions of human resources systems and workplaces in the 
last 20 years, employee happiness has been decreasing day by day. Moreover, according to Great Place to Work data, Turkey's happiness is stated that employees from 45 countries rank the 41st.

The fact that employee happiness is paramount in human resources management is also supported by literature studies (Bilginoğlu \& Yozgat, 2020; Carr, 2010; Fisher, 2010; Chia \& Chu, 2016; Güllü, 2018; Hoise, Willemyns \& Sevastos, 2012; Keser, 2018; Pan and Zhou, 2013; Scott, 2008; Singh \& Aggarwal, 2018; Turan, 2018; Wesarat et al., 2015). According to these studies, in order for human resources management to be successful, the employee should feel commitment and identification due to the high level of internal motivation, job satisfaction, job performance, success and sense of belonging to the organization. Therefore, the employee's positive emotions, perceptions, attitudes and behaviours are related to the employee's happiness. In order to increase employee motivation, job satisfaction and happiness in terms of loyalty and high work performance in today's organizations, happiness departments have also been created in addition to the human resources department. For example, it has been stated by Akduman and Duran (2017) that the happiness department is not yet widely established in our country (in Turkey) and is expressed as the "internal relations department" in some organizations. Therefore, this department is a very new concept in terms of human resources function yet. Even the name of the department as "Happiness department" is an indication that the importance given to employee happiness is very high today.

In this study, by analyzing the studies about employee happiness in terms of human resources management with a systematic literature review, the importance of employee happiness for the success of organizations will be revealed. Organizational behaviour and work attitudes associated with employee happiness in the current literature will be determined with a systematic literature review. Factors associated with employee happiness will be determined. Also, the positive results of employee happiness will be achieved thanks to the findings obtained. In the conclusion part of the study, suggestions will be presented to human resources managers, future researchers and other interested people, thanks to the findings. On the other hand, it is thought that this study, which is about "employee happiness", which has been 
intensely examined especially in 2010 and after, it could add necessary information to the literature by comparing it with other studies in the literature, and could be an essential source of information for future researchers.

\section{EMPLOYEE HAPPINESS}

Studies on employee happiness are scarce in the past (Wesarat, Sharif, \& Majid, 2015: 78). Similarly, it was stated by Carr (2011:384) that previous studies did not care much about the concept of happiness, that is, underestimated. Happiness and employee happiness have taken their place among the studies that have been studied among the organizational behaviour concepts, especially in 2010 and afterwards and associated with other organizational concepts. Work happiness related to employee happiness in recent years (Bilginoğlu \& Yozgat, 2020; Carr, 2011; Fisher, 2010; Keser, 2018; Scott, 2008; Singh \& Aggarwal, 2018; Wesarat et al., 2015) work happiness (Turan, 2018), employee happiness in sports businesses (Güllü, 2018) and the relationship between happiness and stress (Chia \& Chu, 2016) were encountered. Therefore, it can be said that the importance given to employee happiness increased in 2010 and after.

Happiness in the Oxford dictionary (URL-2) is defined as the excellent state of mind, the deep pleasure and satisfaction of the circumstances, in general, or in a particular event, good luck or good luck, success, prosperity, the quality or condition of being happy. In the Cambridge dictionary (URL-3), it is defined as a feeling of being happy. However, Keser (2018: 45) defines happiness as a situation that reflects the positive state of the individual, while Turan (2018: 169) defines work as one of the factors that support one's happiness. On the other hand, Shin and Johnson (1978: 475) defined happiness as a product of firstly evaluating a person's life situations and a favourable comparison of those life situations with others and one's past. Accordingly, employee happiness can be defined as the satisfaction of the employee from his job or his well-being. Besides, it was explained by Bas (2017) that a person could achieve happiness with his job. That is to say, "If a person works harder, he/she will be more successful. If he/she is more successful, he/she will be happier".

In the literature, it is seen that the concept of happiness/employee happiness is used together with concepts such as well-being, employee well-being, employee 
satisfaction, engagement, organizational commitment and job satisfaction (Bilginoğlu \& Yozgat, 2020; Carr, 2011; Güllü, 2018; Keser, 2018; Korkmaz \& Erdoğan, 2014; Kluger \& Tikochinsky, 2001; Ryan \& Deci, 2001; Saager et al., 2012; Singh \& Aggarwal, 2018; Zeng, Forrest \& McHale, 2012). On the other hand, Becker et al. (2013: 136), who evaluated the good or bad mood of the employee in terms of the happiness of the employee, stated that when the employee is in a "bad" mood, the employee experiences negative emotions such as anger and sadness. Also, it was stated that while the employee is in a "good" mood, the employee experiences positive emotions such as happiness and compassion.

According to positive psychology (Carr, 2011: 2), there are three orientations about happiness. A pleasant life, busy life and a meaningful life. These three directions of happiness are about welfare. On the other hand, according to Scott (2008), happiness is part of job satisfaction, but it is really about what you can control and influence. Accordingly, it can be said that as the employees gain the power to control and influence their potential, the work will be made more meaningful, and thus the happiness will increase. It can also be said that employment (Zeng et al., 2012; Wesarat et al., 2015) occupies an important place in employee happiness.

In the studies in the literature, it was stated that happiness at all levels has significant consequences for both individuals and organizations (Carr, 2011; Scott, 2008; Singh \& Aggarwal, 2018). As stated by Turan (2018: 169) in the organizational behaviour studies, the motivation, job satisfaction, performance, commitment and similar concepts related to the employee have been studied in both local and foreign literature, although direct studies on employee happiness are limited. For example, in Turkey, Bilginoğlu and Yozgat (2020: 201-202) by Salas-Valle and Alegre Vidal (2018) in which they develop, "Happiness Scale in the workplace 'has made a study of the Reliability and Validity of Turkish Form. In this study, it was stated that happiness is an issue that needs to be dealt with in terms of management apart from the philosophical point of view in our country, but the studies in the field of management do not show enough interest in happiness, and it creates a critical research gap in this subject. Based on this gap in the literature, it was thought that this study, which was conducted with, could be one of the first steps to close the gap in terms of human 
resources management, which is one of the specific issues of management. Also, this study, apart from filling the gap in the literature, will provide essential benefits in guiding future researchers on which topics related to happiness may be particularly important to research.

\section{SYSTEMATIC LITERATURE REVIEW}

Systematic literature review method was used to reach the aim of this study. When "happiness", "happy", "employee", "manager", "organization" is entered into the search section of the Science Citation Index (SCI) database, a total of 685 articles (URL4) have been reached, including 43 review articles and 642 research articles. 685 articles constitute the central mass of this study. However, since this study is related to human resources, only articles containing the terms in the "Human Resource Management Review" journal are included in the research. When the words "happiness", "happy", "employee", "manager", "organization" are written in the SCI database for the journal "Human Resource Management Review", only 11 articles (URL-5) have been reached. It was concluded that only 11 articles were not sufficient in the context of qualitative evaluation of studies on the concept of happiness. Therefore, "Human Resource Management Review" magazine was selected in the SCI database, and only "happiness" was written in the search section to analyze the articles in which the concept of happiness is used at least once. As a result of the search, 48 articles (URL6), in which the term "happiness" was used at least once, were reached. Thus, 48 articles included in the research, published between 1995-2020, constituted the sample of this study. However, at the stage of reviewing the articles, even if the concept of happiness was used at least once in the text since the concept of happiness used in the article was not related in any way with the employee or the organization, 13 articles (Blau, 2006; Bonache, 2004; Hertel, Geister \& Konradt, 2005; Laken, Engen, Veldhoven \& Paauwe, 2019; London, 1995; Pindek, Koslowsky \& Weisberg, 2010; Pio, 2017; Ravid, Rafaeli \& Grandey, 2010; Samara, Jamali \& Parada, 2019; Sayegh, Anthony \& Perrewé, 2004; Schoenfeldt, 1999; Schumann, 2001; Vecchio, 2003), were excluded from the scope of analysis, and therefore systematic literature analysis has been continued with the remaining 35 articles. While conducting a systematic literature review, SPSS 22.0 
statistical package program and Microsoft Excel program were used. The information about the 35 articles included in the analysis is shown in the table below.

Table 1. Information on the Articles Included in the Analysis

\begin{tabular}{|c|c|c|}
\hline S/No & Author/authors and publication year & $\begin{array}{l}\text { Frequency of use of the } \\
\text { concept "happiness." }\end{array}$ \\
\hline 1 & Albert, Allen, Biggane \& Ma (2015) & 1 \\
\hline 2 & Bailey et al. (2017) & 2 \\
\hline 3 & Becker, Ullrich \& Dick (2013) & 2 \\
\hline 4 & Bouskila-Yam \&Kluger (2011) & 9 \\
\hline 5 & Buckley et al. (2001) & 7 \\
\hline 6 & Cardador, Northcraft \& Whicker (2017) & 1 \\
\hline 7 & Cardon (2008) & 1 \\
\hline 8 & Cartwright \& Holmes (2006) & 3 \\
\hline 9 & Chang \& Shih (2019) & 1 \\
\hline 10 & Cheng \& Hackett (2019) & 4 \\
\hline 11 & Cooke, Wood, Wang \& Li (2020) & 2 \\
\hline 12 & Cropanzano \& Byrne (2001) & 1 \\
\hline 13 & Dries (2013) & 1 \\
\hline 14 & Eby et al. (2019) & 2 \\
\hline 15 & Ferrris, Munyon, Basik \& Buckley (2008) & 1 \\
\hline 16 & Ganster (2008) & 1 \\
\hline 17 & Gullekson \& Dumaisnil (2016) & 2 \\
\hline 18 & Han Sun \& Wang (2019) & 10 \\
\hline 19 & Harms (2011) & 1 \\
\hline 20 & Judge \& Kammeyer-Mueller (2011) & 2 \\
\hline 21 & Kluger \& Nir (2010) & 3 \\
\hline 22 & Kumar, Budhwar, Patel \& Varma (2019) & 1 \\
\hline 23 & Liu \& Perrewé (2005 & 7 \\
\hline 24 & Lopez-Cabrales \& Valle-Cabrera (2019) & 1 \\
\hline 25 & Mamman, Kamoche \& Bakuwa (2012) & 1 \\
\hline 26 & Markman \& Baron (2003) & 1 \\
\hline 27 & Michel, Tews \& Allen (2019) & 1 \\
\hline 28 & Ragins \& Winkel (2011) & 6 \\
\hline 29 & Snir \& Harpaz (2012) & 1 \\
\hline
\end{tabular}




\begin{tabular}{|l|l|c|}
\hline 30 & Spector \& Fox (2002) & 1 \\
\hline 31 & Spence \& Keeping (2011) & 1 \\
\hline 32 & Tews \& Noe (2019) & 1 \\
\hline 33 & Vardaman, Gondo \& Allen (2014) & 5 \\
\hline 34 & Weiss (2002) & 2 \\
\hline 35 & Zapf (2002) & \\
\hline
\end{tabular}

\subsection{FINDINGS}

In the context of systematic literature review, 35 of 48 articles were included in the analysis according to the criteria of "publication in the Human Resources Management Journal in the SCI database, using the concept of happiness at least once in the full text, having a relationship with employee happiness". The other 13 article studies were excluded from the analysis. As a result of examining 35 articles in terms of publication year in the systematic literature review, the frequency distribution of the publications by year is shown in Table 2 below.

Table 2. Frequency Distribution of Studies on Employee Happiness by Publication Years Range

\begin{tabular}{ccc}
\hline Publication Years Range & Frequency & Percent \\
\hline $2001-2005$ & 7 & 20,0 \\
$2006-2010$ & 5 & 14,3 \\
$2011-2015$ & 11 & 31,4 \\
$2016-2020$ & 12 & 34,3 \\
\hline Total & 35 & 100,0 \\
\hline
\end{tabular}

When the Table 2 above is examined, it is seen that although the studies on employee happiness gained importance after 2000, the issue became more and more important, especially due to the increase in publications in 2010 and after. The importance was given to employee happiness in 2010 and beyond has been further demonstrated by the frequency histogram below. Accordingly, it has been observed that studies on employee happiness have intensified especially in 2010 and after 
$(65,7 \%)$

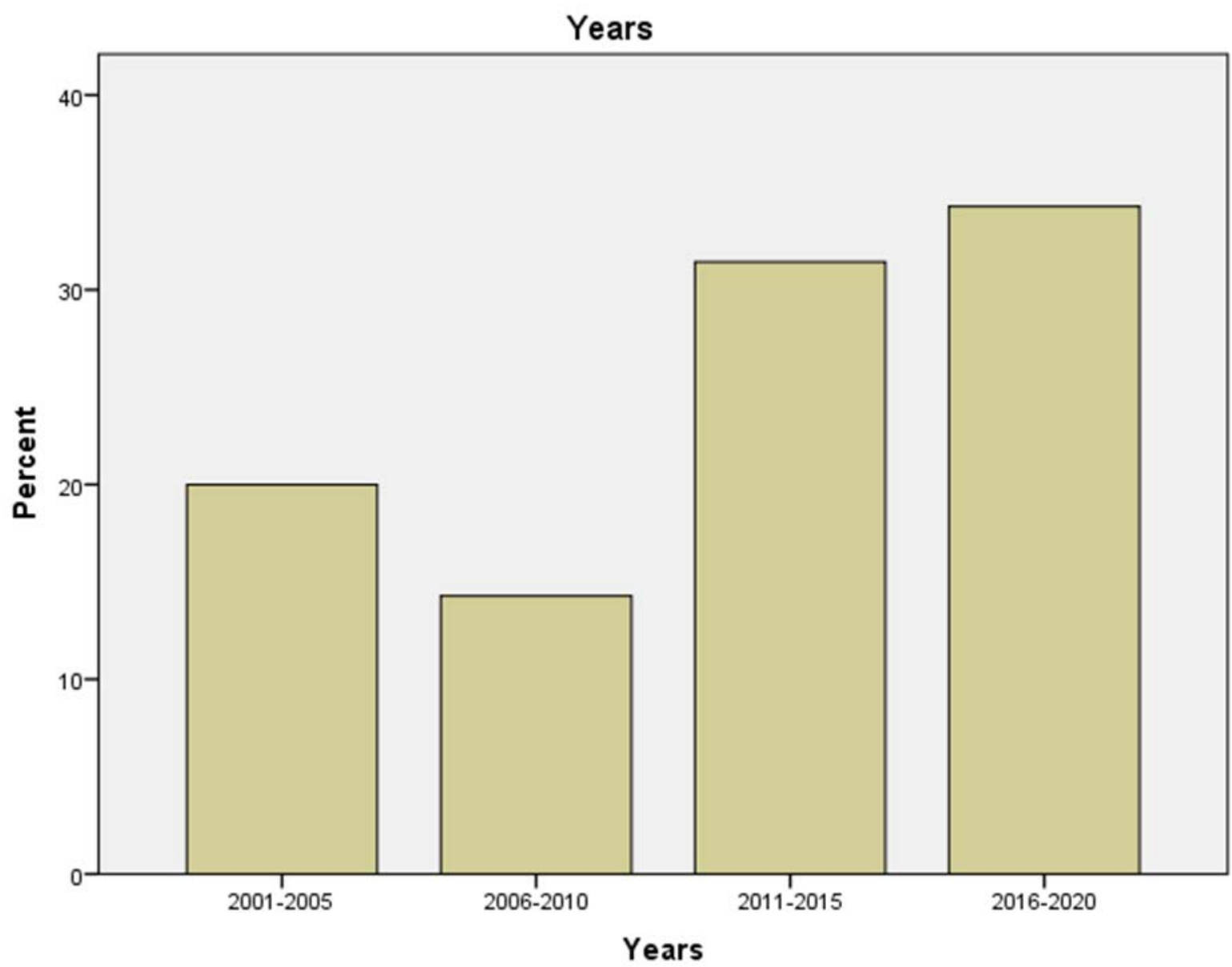

Figure 1. Distribution of Studies on Happiness of Employees by Publication Years

\section{Range}

There is no study published by the academicians of our country in the "Human Resource Management Review" magazine published in the SCI database on employee happiness between 2001-2020. Studies on happiness, employee happiness or work happiness in our country (Akduman, 2020; Akduman \& Duran, 2017; Akın \& Şentürk, 2012; Alparslan \& Yastioğlu, 2018; Bas, 2017; Bilginoğlu \& Yozgat, 2020; Erben \& Ötken, 2014; Erselcan \& Özer, 2018; Güllü, 2018; Işık, Çetinkaya \& Işık, 2017; Korkmaz \& Erdoğan, 2014; Öztaş, 2018; Selim, 2008; Sürücü, 2016; Turan, 2019; Turan, 2018; Yüksekbilgili \& Akduman, 2016) available. However, these studies were excluded as they did not have inclusion criteria for systematic literature review. On the other hand, although they were not included in the systematic literature review because they were not included in the SCI database, when the time intervals of these publications were 
scrutinized, almost all of the publications in our country were published after 2010, and this situation supports the finding in this study. Besides, as stated by Akduman (2020), the fact that the training related to graduate courses was added to the course titled "Employee happiness" shows that the importance given to employee happiness is increasing in our country.

However, the findings obtained regarding the concept of happiness used in 35 articles evaluated through a systematic literature review are given below in alphabetical order according to the author's surnames. Namely;

- A reliable relationship is a critical determinant of an individual's happiness (Albert et al., 2015: 94),

- The meaningful perception of the work done by the employee reveals positive results such as job satisfaction or happiness in business life (Bailey et al., 2017: 420),

- The emotional commitment of the employee directly affects the sense of happiness and also, when they are in a "bad" mood, people experience negative emotions such as anger and sadness, and when they are in a "good" mood, they experience positive emotions such as happiness and compassion (Becker et al., 2013: 136),

- In the Strength-Based Performance Appraisal (SBPA), the concept of "happiness" is related to Positive Psychology, happy people are healthier and more social, and also happy people show a more creative performance than unhappy people (Bouskila-Yam \& Kluger, 2011),

- According to John Stuart Mill's Utilitarian theory, it is necessary to calculate how much happiness will produce various modes of action and choose the mode of action that produces the most happiness, and also that utilitarians should measure happiness and provide information about right and wrong about who is affected by a particular activity (Buckley et al., 2001),

- In the context of work gamification theory, work pleasure is related to joy and happiness experiences (Cardador, Northcraft \& Whicker, 2017),

- $\quad$ "Confident entrepreneurs" share positive emotions with their employees (such as pleasure, happiness and excitement) but do not share negative emotions (such as disappointment, anger, anxiety) (Cardon, 2008: 79), 
- It is the case that happiness can be lived at different levels compared to "a pleasant life, a good life and a meaningful life", accordingly, a pleasant life is shown as the lowest level of happiness, and a good life is associated with enjoying something we are good at. A meaningful life is a life that provides the longest-lasting happiness and provides the highest level of success (Cartwright \& Holmes, 2006: 203),

- A positive feeling such as happiness enhances the creativity performance of the employee (Chang \& Shih, 2019: 11),

- The concept of happiness is considered in the category of job attitudes (Cheng \& Hackett, 2019: 4),

- Employee happiness is counted among the variables for human resources function (Cheng \& Hackett, 2019: 7),

- Employee welfare is considered as "happiness, health and relationship" and also, in studies on employee welfare, psychological well-being (e.g. happiness, organizational commitment and job satisfaction), physical well-being (e.g. physical health) and social well-being (e.g. relationships, organizational justice), accordingly happiness is one of the indicators of psychological well-being (Cooke et al., 2020),

- When employees perceive procedural injustice, they trust their leaders less, they are less happy, and they are more likely to leave the organization (Cropanzano \& Byrne, 2001),

- Positive psychology literature studies examine concepts such as passion, peak performance and job love, and these concepts are generally associated with positive health outcomes such as flow, well-being, happiness and low risk of burnout (Dries, 2013),

- The focus of education is improvements in well-being, and the overall goal is "happiness" (Eby et al., 2019),

- The issues discussed in the work stress literature are issues that go beyond the attitudes and behaviours of employees and are related to the health and happiness of all people (Ganster, 2008: 269), 
- Low-status individuals are more likely to experience anger, boredom, sadness, and fear compared to individuals with higher status, and less likely to experience happiness, and that HRM systems lead to better happiness and relationships but result in worse health (Gullekson \& Dumaisnil, 2016: 265),

- High-performance business systems have an impact on employee happiness (Han Sun \& Wang, 2019),

- Unexpected events or new events result in the first emotional response of happiness or sadness (Ferris et al., 2008),

- While it is thought that reliable individuals will generally establish safe, supportive and happy relationships with their colleagues, individuals who are connected with anxiety will be more prone to worry about their relationships in the workplace and generally report less job satisfaction with higher stress and burnout (Harms, 2011: 290),

- According to the self-adaptation theory, the happiness of the employees will increase when the goals are reached because they fulfil their values (Judge \& Kammeyer-Mueller, 2011),

- $\quad$ "Happiness at work", "optimum performance" or "extraordinary leadership" are among the main success factors in the workplace, and happiness is counted among positive emotions (Kluger \& Nir, 2010: 237),

- When a positive result is achieved in a promotion-oriented self-control system that focuses on growth and success, emotions related to joy such as happiness or satisfaction will emerge (Kumar et al., 2019),

- Emotions should be guided and managed to encourage employees' acceptance into organizational change (Liu \& Perrewé, 2005),

- Some studies on Sustainable Human Resources Management strategies have examined how human resources management improves social sustainability and contributes to the well-being and health of employees through Sustainable Work Systems and others, and others have focused on new concepts such as happiness at work (Lopez-Cabrales \& Valle-Cabrera, 2019),

- The concept of happiness is among the positive emotions used in defining the emotional commitment of the employee (Mamman et al., 2012: 294), 
- The social skills of the employee are effective on the happiness of the employee, job performance and promotion (Markman and Baron, 2003: 292),

- There may be dissatisfaction between the employee's emotions (e.g. anxiety or disappointment) and expected emotions (e.g. happiness and joy) (Michel, Tews \& Allen, 2019),

- As a function of a social contagion effect, happiness indicators are related to the event. Happiness is not necessarily related to the state or ability to influences others in social relationships (Ragins \& Winkel, 2011),

- Workaholicism can create a dangerous situation for personal happiness (Snir \& Harpaz, 2012),

- The concept of happiness is among the positive feelings of the Job-Related Affective Well-Being Scale (JAWS) (Spector \& Fox, 2002),

- Emotional reactions vary according to the state of reaching the goal, accordingly, when the desired goal is reached, a happiness reaction is seen, and a sad reaction is observed when the desired goal is not achieved (Spence \& Keeping, 2011),

- Emotions such as anger, pride, happiness, guilt and similar in the employee can be more distinguished, and these separate feelings may have significantly different causes and consequences (Weiss, 2002),

- Pro-social rule-breaking (PSRB) appears to be a utilitarian decision resulting from the desire to create or maximize positive outcomes according to what the philosopher John Stuart Mill (1863) called the "principle of greatest happiness" (Vardaman et al., 2014: 108-110), and for example, an employee Pro-social rulebreaking behaviour for the welfare (such as happiness) of a subordinate or coworker (Morrison, 2006: 5),

- $\quad$ "Happiness" feeling has a high activation level (Tews and Noe, 2019: 231), for example, "Happiness" feeling is a more intense feeling than satisfaction (Zapf, 2002: 242).

As a result of the systematic examination of the above literature, the relevant factors related to employee happiness can be listed as follows (Albert et al., 2015: 94; Bailey et al., 2017: 420; Becker et al., 2013: 136; Cardon, 2008: 79; Cartwright \& Holmes, 2006: 203, Cooke et al., 2020; Dries, 2013; Eby et al., 2019; Ferris et al., 2008; Gullekson 
\& Dumaisnil, 2016: 265; Han Sun \& Wang, 2019; Harms, 2011: 290; Judge \& KammeyerMueller, 2011, Kluger \& Nir, 2010: 237; Markman \& Baron, 2003: 292; Spence \& Keeping, 2011):

- HRM (Human Resource Management) systems,

- High-performance business systems, optimum performance,

- Outstanding leadership,

- Workplace relationships,

- Trustworthy relationship,

- Meaningful perception of the job,

- Liking the job,

- Emotional commitment,

- Good mood, psychological well-being,

- Improvement in well-being,

- A promotion-oriented self-control system focused on growth/success,

- The manager sharing positive feelings,

- Social skills,

- A pleasant life, a good life or a meaningful life perception,

- Unexpected-pleasing/surprise events,

- Fulfilment of personal values,

- Reaching the desired goal.

Besides, it has been observed that some studies on Sustainable Human Resources Management strategies tend to focus on new concepts such as happiness at work (Lopez-Cabrales \& Valle-Cabrera, 2019). However, employee happiness, in terms of human resources management, is about creative performance, peak performance, high-level success, healthier and social workers, more pleasant employees, emotional commitment and promotion (Bouskila-Yam \& Kluger, 2011; Cardador et al., 2017; Cartwright \& Holmes, 2006: 203, Chang \& Shih, 2019: 11; Dries, 2013; Mamman et al., 2012: 294; Markman \& Baron, 2003: 292). Accordingly, it is expected that the happy employee will show a better performance, show acceptable behaviours, be successful in their job, and will show organizational behaviour and job 
attitudes as well as stay loyal to their job and workplace. Therefore, considering the work attitudes and organizational behaviours, which are observed to affect the happiness of the employee, in all managerial discourse and actions in terms of human resources management, will provide positive organizational results.

\section{RESULTS, DISCUSSIONS AND SUGGESTIONS}

In order for businesses to survive in today's business and competitive environment, human resources, which are among the most important resources, need to work effectively and efficiently. However, whether employees are satisfied or happy with their jobs affects their loyalty, commitment, and thus continuity to their current job and workplace. For this reason, it is essential to ensure employee happiness for the continuation of the availability of highly skilled employees, especially in achieving the long-term goals of the businesses. Because, in the changing business world, individuals can make job changes several times. Leaving the highly skilled employee from the job disrupts the success of the businesses.

The study of the concept of happiness and other concepts related to the concept of happiness in all the articles examined within the scope of the study, with other studies to be carried out in a wider and more detailed way, guides the managers in business life, contributing to the knowledge in the literature, shedding light to other researchers and beneficial to others who are interested in the subject. The following recommendations are presented in order to provide information. Namely; Examining the relationship between the meaning of the job and the happiness of the employee (Bailey et al., 2017: 420); Examining the relationship between secure relationships and employee happiness (Albert et al., 2015: 94); Examining the relationship between the emotional commitment levels and happiness levels of employees (Becker et al., 2013: 136); Examining the relationship between employees' moods and feelings of happiness (Becker et al., 2013: 136); Examining the relationship between ethical organizational culture and employee happiness (Buckley et al., 2001), examining the impact of human resources practices on employee happiness according to Miller's utilitarian theory (Buckley et al., 2001); Examining the relationship between work pleasure and happiness (Cardador et al., 2017: 357); The meaning of the work is to analyze employee 
cynicism (Cartwright \& Holmes, 2006: 199) and employee happiness together; Examining the relationship between employee happiness and job attitude (Cheng \& Hackett, 2019: 4); Examining the relationship between employee well-being and happiness, or psychological well-being with happiness (Cooke et al., 2020: 4); Examining the effect of perceived injustice on employee happiness (Cropanzano \& Byrne, 2001: 32); Examination of the relationship between the concepts in positive psychology literature such as passion, high performance and loving job with happiness (Dries, 2013: 277); Examining the relationship between happiness and organizational concepts in the context of emotional literature (Ferris et al., 2008: 154); Examining the relationship or impact of work experience on mental and physical health (Ganster, 2008: 269); Carrying out studies examining the concepts of work stress, health and happiness together (Ganster, 2008: 269); Examination of the emotions experienced by individuals with different status in the business world, and especially the feelings of happiness, anger, boredom and the way they show these emotions (Gullekson \& Dumaisnil, 2016: 265); To investigate whether the ways of showing emotions of low and high status individuals (Gullekson \& Dumaisnil, 2016: 265) differ in terms of different sectors, culturally or in personality traits; Examining the relationship between high performance working system and employee happiness (Han Sun \& Wang, 2019); Examining the impact of business resources on employee happiness (Han Sun \& Wang, 2019); Examining the relationship between inner motivation and employee happiness (Han Sun \& Wang, 2019); Examining the impact of HRM practices on employee happiness (Han Sun \& Wang, 2019); Conducting research that examines attachment styles and happiness (Harms (2011: 290) concepts together; Examining the effect of basic self-assessment and goal setting (Judge and Kammeyer-Mueller, 2011:333) on the happiness of the employee; Examining the effect of a promotion-oriented self-regulation system on employee happiness (Kumar et al., 2019: 5); Examining the impact of employee happiness on the organizational change process (Liu \& Perrewé, 2005: 274); Determining the level of happiness or loyalty of the employee and the relationship or the mediation role of the employee (Liu \& Perrewé, 2005: 274); Examining the relationship between sustainable human resources and happiness (Lopez-Cabrales \& Valle-Cabrera, 2019: 2); Examining the effect or role 
of the concept of "happiness here" on "sustainable HRM strategies" (Lopez-Cabrales \& Valle-Cabrera, 2019: 2); Examining the relationship between employee happiness and emotional commitment (Mamman et al. 2012: 294); Examining the effect of employee social skills on performance and promotion (Markman \& Baron, 2003: 292); Investigating the effects of employee social skills on job attitude and job outcomes (Markman \& Baron, 2003: 292) and conducting research to determine the effect of social skills on employee happiness (Markman \& Baron, 2003: 292); Examining the mediating role of happiness in the effect of entertainment at work (Michel et al., 2019: 105) on job attitudes; Examining the effect of happiness on social relations (Ragins and Winkel; 2011: 380); Examination of the relationship of those who have power with smiling employees (Ragins and Winkel; 2011: 380); Examination of pressure difference (Ragins and Winkel; 2011: 380) on the smiling or non-smiling employees of those with power; Investigation of the effects of low activation and high activation emotions (Tews \& Noe, 2019: 231) on job attitudes; Examination of the relationship between prosocial rule chewing (PSRB) and Stuart Mill (1863) " principle of happiness' (Vardaman et al., 2014: 110); Investigation of the effects of momentary affective states on many work behaviors, not general happiness levels (Weiss, 2002: 182); Examining the relationship between subjective well-being and happiness in life (Weiss, 2002: 182); Examination of the relationship between intense/less intense emotions and feeling of happiness (Zapf, 2002: 242).

Besides, as a result of the systematic literature review, it was observed that in the works of Zapf (2002: 242) and Tews \& Noe (2019: 231), happiness is more intense than satisfaction and has a higher level of activation. Accordingly, it can be said that happiness will increase as satisfaction increases in the business environment. The relationship between satisfaction and happiness, the severity of this relationship and its impact on organizational outcomes can be determined by other research. On the other hand, the study on Power Based Performance Evaluation published by BouskilaYam and Kluger (2011) was found interesting and examined in detail. As a result of the review, the following recommendations were made to future researchers regarding employee happiness: 
- The relationship between creativity, creative performance, power-based performance, organizational citizenship behaviour and other organizational results and employee happiness can be examined.

- Human resources practices that increase employee happiness and reduce depression can be examined.

This study has its limitations. First of all, the first constraint is that because the study was made on the days of the Covid-19 pandemic, institutional connections to online databases could not be made due to home-office work and flexible working hours. The second constraint is that high wages are required in achieving studies. The third constraint is that this study is based only on the studies published in the journal Human Resource Management Review, scanned on the SCI database. A more comprehensive study of future researchers will reveal the depth and importance of the subject. For this reason, providing free access to articles published by academics and other researchers will be one of the greatest contributions to the scientific world and especially to humanity.

In addition, this study supports the research conducted by Bilginoğlu and Yozgat (2020). The application of the "Happiness at Work Scale" adapted into Turkish by Bilginoğlu and Yozgat on all employees, including different sectors and different management levels, can be suggested to future researchers. In this way, both business managers can be made suggestions that will increase the happiness of the employees, and the gap in the literature can be filled in terms of human resources management. 


\section{REFERENCES}

Akduman, G. (2020). The effect of Employee Happiness Course on Subjective Well-being and Job

Related Well-being: A Relational-Causal Screening Study on Graduate Students. Journal of Organizational Behavior Review, 2 (2), 90-114. Retrieved from https:// dergipark.org.tr/en/pub/jobreview/issue/56152/706355

Akduman, G. and Duran, N. (2017). The Importance of Employee Satisfaction in Organizations and A New Concept in Human Resources: The Department of Happiness, International Social Research Congress, 20 - 22 April 2017 / Istanbul ISBN: 978-605-82729-0-3

Albert, L. S., Allen, D. G., Biggane, J. E. and Ma, Q. (K) (2015). Attachment and responses to employment dissolution. Human Resource Management Review, 25, 94-106.

Alparslan, A. M. \& Yastioğlu, S. (2018). A Field Research on Priority Managers Virtues for Happy Employee. Journal of Administrative Sciences, 16 (32), 629-650.

Bailey, C., Madden, A., Alfes, K., Shantz, A. and Soane, E. (2017). The mismanaged soul: Existential labor and the erosion of meaningful work. Human Resource Management Review, 27, 416-430.

Bas, T. (2017). Joy.ology: The Chemistry of Happiness. Retrieved on 13.08.2020 from amazon.com/Joyology-Chemistry-Turker-Bas-PhD/dp/1973365340.

Becker, T. E., Ullrich, J. \& Dick, R. v. (2013). Within-person variation in affective commitment to teams: Where it comes from and why it matters. Human Resource Management Review, 23, 131-147.

Bilginoğlu, E. \& Yozgat, U. (2020). The Validity and Reliability of the Happiness at Work Scale- Turkish Form. Journal of Yasar University, 15 (Special Issue), 201-206.

Blau, G. (2006). A process model for understanding victim responses to worksite/function closure. Human Resource Management Review, 16, 12-28.

Bonache, J. (2004). Towards a re-examination of work arrangements: An analysis from Rawls' Theory of Justice. Human Resource Management Review, 14, 395-408.

Bouskila-Yam, O. and Kluger, A. N. (2011). Strength-based performance appraisal and goal setting. Human Resource Management Review, 21, 131-147.

Buckley, M. R., Beu, D. S., Frink, D. D., Howard, J. L., Berkson, H., Mobbs, T. A. and Ferris, G. R. (2001). Ethical issues in human resources systems. Human Resource Management Review, 11, 11-29.

Cardador, M. T., Northcraft, G. B. and Whicker, J. (2017). A theory of work gamification: Something old, something new, something borrowed, something cool? Human Resource Management Review, 27, 353-365.

Cardon, M. S. (2008). Is passion contagious? The transference of entrepreneurial passion to employees. Human Resource Management Review, 18, 77-86. 
Carr, A. (2011). Positive Psychology- The Science of Happiness and Human Strengths. Second Edition, Routledge: London and Newyork.

Cartwright, S. and Holmes, N. (2006). The meaning of work: The challenge of regaining employee engagement and reducing cynicism. Human Resource Management Review, 16, 199-208.

Chang, Y.-Y., Shih, H.-Y. (2019). Work curiosity: A new lens for understanding employee creativity. Human Resource Management Review, 29, 100672.

Cheng, M. M. and Hackett, R. D. (2019). A critical review of algorithms in HRM: Definition, theory, and Practice. Human Resource Management Review, https://doi.org/10.1016/j.hrmr.2019.100698 Date of access: 21.02 .2020

Chia, Y. M. and Chu, M. J. T. (2016). Moderating effects of presenteeism on the stress-happiness relationship of hotel employees: A note. International Journal of Hospitality Management, Volume 55, Pages 52-56. https:// doi.org/10.1016/j.ijhm.2016.02.005 Date of access: 16.05.2020

Cooke, F. L., Wood, G., Wang, M. And Li, A. S. (2020). Riding the tides of mergers and acquisitions by building a resilient workforce: A framework for studying the role of human resource management. Human Resource Management Review, https://doi.org/10.1016/j.hrmr.2020.100747 Date of access: 21.02.2020

Cropanzano, R. and Byrne, Z. S. (2001). When it's time to stop writing policies, An inquiry into procedural injustice. Human Resource Management Review, 11, 31-54.

Dries, N. (2013). The psychology of talent management: A review and research agenda. Human Resource Management Review, 23, 272-285.

Eby, L. T., Allen, T. D., Conley, K. M., Williamson, R. L., Henderson, T. G. and Mancini, V. S. (2019). Mindfulness-based training interventions for employees: A qualitative review of the literatüre. Human Resource Management Review, 29, 156-178.

Erben, G. S. \& Ötken, A. B. (2014). The Role of Work-Life Balance in The Relationship Between Paternalistic Leadership and Work Related Well Being. Journal of Management and Economics Studies, Issue: 22. Doi: http://dx.doi.org/10.11611/JMER192

Erselcan, R. C. \& Özer, P. S. (2018). A Research on the Mediating Role of Happiness to the Impact of Job Satisfaction to Performance. Journal of Entrepreneourship and Development, 13 (2), 148-165.

Ferris, G. R., Munyon, T., P., Basik, K. And Buckley, M. R. (2008). The performance evaluation context: Social, emotional, cognitive, political, and relationship components. Human Resource Management Review, 18, 146-163.

Fisher, C. D. (2010). Happiness at Work. International Journal of Management Reviews, Vol. 12, 384-412. DOI: $10.1111 /$ j.1468-2370.2009.00270.x 
Ganster, D. C. (2008). Measurement challenges for studying work-related stressors and strains, Human Resource Management Review, 18, 259-270.

Gullekson, N. and Dumaisnil, A. (2016). Expanding horizons on expatriate adjustment: A look at the role of emotional display and status. Human Resource Management Review, 26, 260-269.

Güllü, S. (2018). Employee happiness in sports businesses. International Journal of Social Sciences and Education Research, Volume 4 (3), 547-559.

Han, J., Sun, J.-M. And Wang, H.-L. (2019). Do high performance work systems generate negative effects? How and when? Human Resource Management Review, https:// doi.org/10.1016/j.hrmr.2019.100699 Date of access: 21.02.2020

Harms, P. D. (2011). Adult attachment styles in the workplace. Human Resource Management Review, 21, 285-296.

Hertel, G., Geister, S. and Konradt, U. (2005). Managing virtual teams: A review of current empirical research. Human Resource Management Review, 15, 69-95.

Hoise, P., Willemyns, M. and Sevastos, P. (2012). The impact of happiness on managers' contextual and task performance. Asia Pacific Journal of Human Resources, 50 (3). DOI: 10.1111/j.1744-7941.2012.00029.x Işık, Z., Çetinkaya, N. \& Işık, M. F. (2017). The Role of Happiness on Job Satisfaction: An Application on Female Employees in the Hospitality Business that is Located at Province of Erzurum Palandöken Winter Tourism Center. Atatürk University Journal of Social Sciences Institute, 21(2), 457-471.

Joo, B. K. and Lee, I. (2017), "Workplace happiness: work engagement, career satisfaction, and subjective well-being", Evidence-based HRM, Vol. 5 No. 2, pp. 206-221. https://doi.org/10.1108/EBHRM-04-20150011

Judge, T., A. and Kammeyer-Mueller, J. D. (2011). Implications of core self-evaluations for a changing organizational context. Human Resource Management Review, 21, 331-341.

Keser, A. (2018). Happiness at Work Survey. PARADOKS Economics, Sociology and Policy Journal, Vol. 14, Number 1, 43-57.

Kluger, A. N., \& Tikochinsky, J. (2001). The error of accepting the "theoretical" null hypothesis: The rise, fall and resurrection of common sense hypotheses in psychology. Psychological Bulletin, 127, 408-423.

Kluger, A. N. and Nir, D. (2010). The feedforward interview. Human Resource Management Review, 20, 235-246.

Korkmaz, O. \& Erdoğan, E. (2014). The Effect of Work- Life Balance on Employee Satisfaction and Organizational Commitment. Ege Academic Review, 14 (4), 541-557. 
Kumar, R., Budhwar, P., Patel, C. and Varma, A. (2019). Self-regulation and expatriate adjustment: The role of regulatory fit. Human Resource Management Review, 29, 100666.

Laken, P. A., Engen, M.L., Veldhoven, M. J. P. M. and Paauwe, J. (2019). Fostering expatriate success: A meta-analysis of the differential benefits of social support. Human Resource Management Review, 29, 100679.

Liu, Y. and Perrewé, P. L. (2005). Another look at the role of emotion in the organizational change: A process model. Human Resource Management Review, 15, 263-280.

London, M. (1995). Giving Feedback: Source-centered antecedents and consequences of constructive and destructive feedback. Human Resource Management Review, Volume 5, Number 3, 159-188.

Lopez-Cabrales, A. and Valle-Cabrera, R. (2019). Sustainable HRM strategies and employment relationships as drivers of the triple bottom line. Human Resource Management Review, https:// doi.org/10.1016/j.hrmr.2019.100689 Date of access: 21.02.2020

Mamman, A., Kamoche, K. and Bakuwa, R. (2012). Diversity, organizational commitment and organizational citizenship behavior: An organizing framework. Human Resource Management Review, 22, 285-302.

Markman, G. D. and Baron, R. A. (2003). Person-entrepreneurship fit: why some people are more successful as entrepreneurs than others. Human Resource Management Review, 13, 281-301.

Michel, J. W., Tews, M. J. and Allen, D. G. (2019). Fun in the workplace: A review and expanded theoretical perspective. Human Resource Management Review, 29, 98-110.

Oswald, A. J., Proto, E. And Sgroi, D. (2015). Happiness and Productivity. Journal of Labor Economics, Volume 33, Number 4. https://www.journals.uchicago.edu/doi/abs/10.1086/681096 A. D.: 25.05.2020

Öztaş, İ. (2018). Determining Leisure Satisfaction and Happiness Levels of State Employees Working in Different Institutions (Kirıkkale Province Sample). It was reached on 13.08 .2020 at http://194.27.217.26/xmlui/handle/20.500.12501/480.

Pan, J. and Zhou, W. (2013). Can success lead to happiness? The moderators between career success and happiness. Asia Pacific Journal of Human Resources, 51, p. 63-80. doi:10.1111/j.1744-7941.2012.00033.x

Pindek, S., Koslowsky, M. And Weisberg, J. (2019). Human resource management in Israel: A multifaceted perspective (Editorial). Human Resource Management Review, 20, 173-175.

Pio, E. (2007). HRM and Indian epistemologies: A review and avenues for future research. Human Resource Management Review, 17, 319-335.

Ragins, B. R. and Winkel, D. E. (2011). Gender, emotion and power in work relationships. Human Resource Management Review, 21, 377-393. 
Ravid, S., Rafaeli, A. and Grandey, A. (2010). Expressions of anger in Israeli workplaces: The special place of customer interactions. Human Resource Management Review, 20, 224-234.

Ryan, R. M. and Deci, E. L. (2011). On Happiness and Human Potentials: A Review of Research on Hedonic and Eudaimonic Well-Being. Annual Review of Psychology, Vol. 52, 141-166. https://doi.org/10.1146/annurev.psych.52.1.141

Sageer, A., Rafat, S. ve Agarwal, P. (2012) "Identification of Variables Affecting Employee Satisfaction and Their Impact on the Organization". IOSR Journal of Business and Management, 5(1): 32-39.

Salas-Vallina, A., Alegre, J., Fernández Guerrero, R. (2018). Happiness at work in Knowledge-intensive Contexts: Opening the Research Agenda, European Research on Management and Business Economics, 24(3), 149-159.

Samara, G., Jamali, D. and Parada, M. J. (2019). Antecedents and outcomes of bifurcated compensation in family firms: A multilevel view. Human Resource Management Review, https://doi.org/10.1016/j.hrmr.2019.100728 Date of access: 21.02.2020

Sayegh, L., Anthony, W. P. and Perrewe', P. L. (2004). Managerial decision-making under crisis: The role of emotion in an intuitive decision process. Human Resource Management Review, 14, 179-199.

Schoenfeldt, L. F. (1999). From dust bowl empiricism to rational constructs in biographical data. Human Resource Management Review, Volume 9, Number 2, 147-167.

Scott, D. (2008). Happiness at Work. Center for American Nurses-Nursing that Works, http://citeseerx.ist.psu.edu/viewdoc/download?doi=10.1.1.605.2406\&rep=rep1\&type=pdf 25.05.2020

Schumann, P. L. (2001). A moral principles framework for human resource management ethics. Human Resource Management Review, 11, 93-111.

Selim, S. (2008). An Analysis on The Values of Individual Happiness Sources in Turkey: Multinomial Logit Model. Journal of the Cukurova University Institute of Social Sciences. 2008, Vol. 17 Issue 3, p345-358.

Shin, D. C. and Johnson, D. M. (1978). Avowed happiness as an overall assessment of the quality of life. Social Indicators Research, 5, 475-492.

Singh, S. and Aggarwal, Y. (2018). Happiness at Work Scale: Construction and Psychometric Validation of a Measure Using Mixed Method Approach. J Happiness Stud, 19, 1439-1463. https://link.springer.com/article/10.1007/s10902-017-9882-x 25.05.2020

Snir, R. and Harpaz, I. (2012). Beyond workaholism: Towards a general model of heavy work investment. Human Resource Management Review, 22, 232-243.

Spector, P. E. and Fox, S. (2002). An emotion-centered model of voluntary work behavior, Some parallels between counterproductive work behavior and organizational citizenship behavior. Human Resource Management Review, 12, 269-292. 
Spence, J. R. and Keeping, L. (2011). Conscious rating distortion in performance appraisal: A review, commentary, and proposed framework for research. Human Resource Management Review, 21, 85-95.

Sürücü, Ö. (2016). Optimism, Life Satisfaction and Happiness in Professional Life; An Application For Hotel Employee. Journal of International Social Research, 9 (43), 2170-2176.

Tews, M. J. and Noe, R. A. (2019). Does training have to be fun? A review and conceptual model of the role of fun in workplace training. Human Resource Management Review, 29, 226-238.

Turan, N. (2019). Factors affecting the working happiness of a public university staff: Qualitative research example. Journal of Economy Culture and Society. Advance online publication. https:// doi.org/10.26650/JECS2019-0011 Reached on 13.08.2020.

Turan, N. (2018). Çalışma Mutluluğu: Kavram ve Kapsam, Uludă̆ Journal of Economy and Society, Volume 37, Issue 1, pp. 169-212.

Vardaman, J. M., Gondo, M. B. and Allen, D. G. (2014). Ethical climate and pro-social rule breaking in the workplace. Human Resource Management Review, 24, 108-118.

Vecchio, R. P. (2003). Entrepreneurship and leadership: common trends and common threads. Human Resource Management Review, 13, 303-327.

Weiss, H. M. (2002). Deconstructing job satisfaction, Separating evaluations, beliefs and affective experiences. Human Resource Management Review, 12, 173-194.

Wesarat, P., Sharif, M. Y. and Majid, A. H. A. (2015). A Conceptual Framework of Happiness at the Workplace. Asian Social Science, Vol. 11, No 2, 78-88.

Wright, T. A. (2005). The role of "happiness" in organizational research: Past, present and future directions. In P. L. Perrewé \& D. C. Ganster (Eds.), Research in occupational stress and well-being: Vol. 4. Exploring interpersonal dynamics (p. 221-264). Elsevier Science/JAI Press.

Yüksekbilgili, Z. \& Akduman, G. (2016). The Relation Between Happiness and Work Addiction. KOSBED, 31, 95-112.

Zapf, D. (2002). Emotion work and psychological well-being: A review of the literature and some conceptual considerations. Human Resource Management Review, 12, 237-268.

Zeng, Z., Forrest, D. and McHale, I. G. (2012). Happiness and Job Satisfaction in a Casino-Dominated Economy, J Gambl Stud, 29, 471-490. https://link.springer.com/article/10.1007/s10899-012-9318-9 25.05.2020 


\section{USED LINKS}

URL-1:

https://indigodergisi.com/2019/01/calisan-mutlulugu-siralamasi/ Date of Access: 12.08.2020

URL-2:

https://www.oed.com/viewdictionaryentry/Entry/84070 Date of Access: 25.05.2020

URL-3:

https://dictionary.cambridge.org/tr/s\%C3\%B6zl\%C3\%BCk/ingilizce/happiness Date of Access: 25.05.2020

URL-4:

https: / / www.sciencedirect.com/search/advanced?qs=\%22happiness $\% 22 \% 2 \mathrm{C} \% 20 \% 22$ happy $\% 22 \% 2 \mathrm{C}$ $\% 20 \% 22$ employee $\% 22 \% 2 \mathrm{C} \% 20 \% 22$ manager $\% 22 \% 2 \mathrm{C} \% 20 \% 22$ organization $\% 22$ Date of Access: 21.02.2020

URL-5:

https://www.sciencedirect.com/search/advanced?qs=\%22happiness $\% 22 \% 2 \mathrm{C} \% 20 \% 22$ happy $\% 22 \% 2 \mathrm{C}$ $\% 20 \%$ 22employee $\% 22 \% 2 \mathrm{C} \% 20 \% 22$ manager $\% 22 \% 2 \mathrm{C} \% 20 \% 22$ organization $\% 22 \&$ pub=Human $\% 20$ Reso urce\%20Management $\%$ 20Review\&cid=272047 Date of Access: 21.02 .2020

URL-6:

https://www.sciencedirect.com/search/advanced?qs=\%22happiness\%22\&pub=Human\%20Resource \%20Management\%20Review\&cid=272047 Date of Access: 21.02.2020 